\title{
Plan International and Its Contribution to the Global Civil Society
}

\author{
Sofya Khlebnikova \\ International University in Geneva
}

While the Global Civil Society is considered as mostly an idealistic notion, the international nongovernmental organization called The PLAN International makes effective contributions to the fight for security of children's in particular girls' rights and equality through "Because I am a Girl" campaign and achieve successful changes through mutually beneficial partnership with the UN Women.

The eagerness to observe the notion of global civil society in action made me look in depth of the hard work that has been done and is going nowadays by one of international non-governmental organizations called PLAN International. The PLAN International promote the faith in the youngsters and focus on rights for protection, health and education. Its beneficial contribution through active participation in civil society prosperity and campaigns for change, such as "Because I am a Girl" not only constructed its authority on the international arena but makes us construct a better governance and grow a stronger society overall.

Keywords: global civil society, NGO, plan international, women's rights, UN, equality, campaigns, partnership

\section{INTRODUCTION}

The Non-governmental organizations are what most analysts refer to as "global civil society" and "enforcers of unenforced human rights" (Kaldor, 2005, p.106). "As a result of the crises and the decreased ability of governments to mitigate them, non-governmental actors become the advocates of the needs, interests, and values of people at large, thus further undermining the role of governments in response to challenges posed by globalization and structural transformation" (Castells, 2008, p.78).

There are 17 sustainable development goals (SDG) in the 2030 Agenda that represent problems which we continue to make progress on (UN Women, 2016). While the UN is the 'promoter' of the need for actions, its role is less effective without the support and 'togetherness' of local, regional, and international actors constantly advocating for the change in different part of the world. Children's rights and Gender Equality are ones of the sensitive issues that interlink the global goals and for which UN Bodies actively fight, and, as Ban Ki-moon mentioned, which require "strong, inclusive and integrated partnerships at all levels" (UN, 2017).

One of the leading activists that deservedly gained trust of the civil society; thus, the attention of the UN Body, such as UNICEF and UN Women, and created an influential interlacement between these two goals is PLAN International.

Moreover, as shown by the speech of Ms. Lakshmi Puri on the event "No Girl Left Behind: Unlocking Data to Power the Girls" organized by PLAN International in October 2016: "As stated by Plan 
International, we lack data to fully capture the realities of girls in poor communities." - the voice of the non-governmental organizations indeed makes the difference when the reputation add the weight to the voice of organization, especially when it is supported by further initiatives as "The launch of Plan International's new report on 'Counting the Invisible: Using Data to Transform the Lives of Women and Girls by 2030' " (Puri, 2016) ${ }^{1}$.

PLAN International's 80 years of experience prove the importance of such issues as vulnerable Children's especially girls' rights, 'must-have' fairness, education and equality. Their partnership with different actors, global activism and visual work on lives' transformations of those who thrive for it, can be seen through campaigns, such as "Because I am a Girl" campaign, consultation, active engagement with the civil society and collaboration with other organizations and the UN Bodies that promotes multistakeholder approach. "Because I am a Girl" campaign was not only a successful start for an influential direction towards girls' equality in fighting for children's rights, not only raised bigger awareness for a new more generalized 'substitute' movement "Girls get Equal", but also it influenced the reputation and further partnerships with the 'like-minded' organizations and the UN as well.

\section{PLAN INTERNATIONAL}

Plan International became trustworthy and reliable by constantly searching for fair and 'just world' (Plan International-History, 2017). Its outcome-oriented activities all over the world during years of its existence continue to play an important role in Children's education in emergency and unjust environments as well as promoting girls' education and equality (Plan International - History, 2017). As PLAN International states itself: "Drawing on more than 75 years of experience and program evidence and connecting to the lives of millions of children, youth and communities around the world, our advocacy targets changes to policies, resource allocation, legislation, institutions and practices so that both current and future generations can realize their rights and fulfill their potential" (Plan International - Policy, Advocacy, Campaigns, 2017).

The history of the organization dates back to 1937: "The organization was set up by British journalist John Langdon-Davies and refugee worker Eric Muggeridge in 1937, with the original aim to provide food, accommodation and education to children whose lives had been disrupted by the Spanish Civil War." (Castells, 2008, p.80).

Bringing the idea of personal "relationship between a child and a sponsor" to life by providing the targeted support for each child, throughout time the Plan International developed further from supporting displaced children in war to targeting the developing countries' education for vulnerable children, from support children in emergency situations and conflicts internationally to fighting against child marriage, from transforming girl's lives through ensuring the education through the active "Because I am a Girl" campaign to strive for bigger and higher goal of promoting the value girls and young women can bring to the world through the "Girls Get Equal" campaign and actively contributing to the youth activism and gaining accountability and the valuable voice in the UN Bodies (Castells, 2008, p.85; Plan International The right to inclusive quality education, 2017).

\section{Advocacy Technique and Forms of Participation}

Whether active support or direct collaboration with other actors is performed nowadays in order to make a change more rapidly and effectively. Global corporate partnerships with organizations such as Nickelodeon, Barclays, Accenture, CBRE, Prudence Foundation, Credit Suisse, Schwarzkopf, and Telenor not only show visual results but also help to grow the network and reliability PLAN International promotes (Plan International - Global Corporate Partnership, 2017).

There are many examples of active participation of Plan International the organization is taking such as launching a campaign "Because I am a Girl", involve in partnership with big corporations such as Nickelodeon and being a part of the steering committee in the Global Coalition to Protect Education from Attack (GCPEA). 
Moreover, there are some outstanding results that can be seen due to the dedication and work of Plan International such as: "A coalition of NGO partners helped 14 southern African states create a model law to harmonize national laws preventing child marriage.", "Working with the Sindh and Gilgit-Baltistan governments, Plan International Pakistan secured a ban on corporal punishment in education.", "Thousands of girls and boys groups share experiences of Colombia's civil war to work for peace and reconciliation in their communities" (Plan International - Global Corporate Partnership, 2017).

"Through more than 500 girls-focused projects, Plan International helped transform the lives of more than 1.9 million girls in 2015 - bringing the total to almost 5 million girls directly reached since Because I am a Girl launched in 2012. In that same period, the lives of more than 40 million girls and boys were indirectly improved as a result of Plan International's work, showing the impact gender programming has on broader communities, schools and families" (Plan International - Global Corporate Partnership, 2017).

\section{"BECAUSE I AM A GIRL" CAMPAIGN}

A simple concern and unfair treatment can trigger the global change in the global community. In particular, the sensitive issue was born when the former director saw the girl in Nepal with not enough clothes on her what was justified by her mom with one phrase "Because she is a girl". This campaign started the growth of advocacy towards girls and helped the transformation of the girls' lives happen in more than 70 countries (Plan International - Because I am a Girl, 2018). It "focuses on giving girls equal opportunities, whether that means changing laws, improving education, improving sexual health services or providing support" (Plan International - Telegraph, 2017).

From 2007, for 8 years the series of annual reports on young women and girls were released, bringing "together leading thinkers, activists and policymakers" who contributed and collected data on injustice towards girls. In 2011 Plan International went further and not without a support, this time from the Canadian government, it reached the UN and made a small step possible where the "11 October as International Day of the Girl in 2011." was adopted (Plan International - Telegraph, 2017).

In 2012 the campaign was launched and there were several activities committed to raise awareness during the following years: from raising awareness by projecting pink on the world heritage buildings and landmarks to "600 young people led by Malala Yousafzai" promoting "urgent prioritization of education around the world" in 2013, from making activity programs becoming urgent and globally supported such as "Safer Cities and Champions of Change initiatives", 'Raise Your Hand' petition to prioritize girls' education in the UN goals ${ }^{2}$, from using media advances to fight against child marriage ${ }^{3}$ to the first global

\#GirlsTakeover movement ${ }^{4}$, from raising the $\mathrm{UN}$ awareness about safety of cities for girls ${ }^{5}$ to raising the budgets for education in developing countries with the support of the campaign \#WeAreTheNext ${ }^{6}$ (Plan International - Telegraph, 2017).

The global campaign "Because I am a Girl" gave a birth to the whole action program that continues through other active approaches the organization is taking; however, this campaign continues on a national level in countries such as Australia, Finland, Denmark, Canada, Sweden, USA, UK, and Switzerland in order to target further improvements on this fundamental level, while letting the organization moving further its agenda and setting, one can say, broader and higher goal to continue the fight for rights on a new level (Plan International - Telegraph, 2017).

In continuation of the movement for the equality for girls, PLAN International moves its relatively specific campaign "Because I am a Girl" ensuring the equality through education and development of fair treatment to the more advanced and at the same time broad target with the "Girls Get Equal" campaign ensuring that their voices are heard. The "Girls Get Equal" is youth-led that "ensuring every girl and the young woman has power over her life and the world around her." The campaign is different from others because the Plan International taking the approach to tackle a more advanced issue of the value in the society compare to the goal of fighting for a mandatory basis for the education for girls, to move forward in the development of young women rights (Plan International - Girls Get Equal, 2017). 


\section{The UN Women and PLAN International collaboration}

By actively engaging with children, youngsters, individual supporters, as well as big and small partners they make the voices be heard, which help the organization build trust and therefore, be able to gain a consultative status in the UNGA and make its role and contribution to be in request for such institutions as UN Women. The active collaboration with UN Women affects the process of activism talks to take place and changes to appear.

From the 2012 when the "Because I am a Girl" campaign was launched, the UN Women not only have shown its respect to the activism initiative, but also contributing to the process of reaching out to the attention of the civil society as well as gaining acceptance of the international institutions as the result of small 'boomerang effect' in the further development of the movement as well as being able to develop strategic partnership with PLAN International in 2016 (Bachelet, 2012; Plan International - UN and Plan International in Global Action for girls, 2017).

The UN Women and PLAN International collaboration is an exemplary relation in the multistakeholder's approach, where the civil society voices reflected through the activities of PLAN International: "The partnership will draw on the experience of Because I am a Girl, Plan International's girls' rights movement and UN Women's Youth and Gender Equality Strategy framework" (Plan International - 100 Million Reasons / Strategy, 2017) ${ }^{7}$. Moreover, as The Strategic Plan 2018-2020 outlines, the UN Women represents 'normative support' and provide coordination and operational activities for system of partnerships it develops in order to achieve the goals of the Plan by 2030 (UN Women - UN Women Strategic Plan 2018-2021, 2017). One of these partnerships is PLAN International and part of its effectiveness maximizing strategies is to participate in and 'deepen partnerships' as well as strong advocacy and successful campaigns for children especially girls with the greater impact as well as to be a leading example of support and 'leave no one behind' (Plan International - 100 Million Reasons / Strategy, 2017).

\section{CONCLUSION}

The concept of Global Civil Society is vague, it is interpreted as an idealistic principle on a theoretical perspective; however, on a practical perspective one can see the growing contribution and outstanding campaigns with societies understanding more about responsibilities they need to share.

The PLAN International promote the faith in the youngsters and focus on protection of health, rights and education.6 PLAN International believes are shared globally as it is a pure multi-stakeholder approach: "Together with global civil society and private sector partners, the initiative will utilize existing and new quantitative and qualitative data and monitor strategically chosen gender-related SDG indicators to track the progress being made for girls and women across key lifecycle stages - an important step to ensure women's and girls' development and rights remain firmly on the agenda" (Plan International - Partnership will make global goals count for girls, 2016).

The success of "Because I am a Girl" campaign was about two-sides of one successful story. On the one hand, the organization promoted the urgency of the issues that civil society concerned about and therefore, made the international institutions such as the UN listen to them. On another hand, civil society's trust and contribution in activities throughout the campaign enhanced accountability and strengthened the voice of the organization to the level that the international institutions such as UN Bodies search for collaboration through partnerships with it. Moreover, as the collaboration with the UN Women shows, one civil society actor can not only formally be in a consultative status, but also get into the effective activism stage with its actions raising the global comprehension. Moreover, the PLAN International is the humanitarian and non-profit organization striving for the development; therefore, doesn't stick to one approach to raise education for girls forever, but after achieving concrete level of achievement move to the more advanced goal to make these educated voices heard. 


\section{ENDNOTES}

1. PLAN International initiatives to the UNGA are more than consultative status as the organization proactively fights for what it stands for. One of the such contribution is the new 'data-tracker' to monitor developments on 'gender targets in the SDGs'. As it explains this 'data-tracker is a "new multi-partner global research project" that "will measure progress for girls and women to ensure governments deliver on their promises for equality by 2030" ("UN and Plan International in Global Action for Girls."; "Partnership Will Make Global Goals Count for Girls."). As explained further, this is "the joint initiative, led by groups including Plan International, the International Women's Health Coalition, KPMG, ONE Campaign and Women Deliver, will ensure decision-makers are held to account on promises to achieve true equality for girls and women during the 15-year implementation of the world's development goals." ("Partnership Will Make Global Goals Count for Girls.") The reasoning for this program is the impossibility to count every little piece of information in when it comes to collect data from the developing countries and less quantifiable data from other countries as well. As was correctly observed: "In many countries, the data we need on girls and women doesn't exist yet, is incomplete or is not being compiled effectively," says Plan International's Chief Executive Anne-Birgitte Albrectsen. "Millions of girls are left invisible so we don't have the information to persuade governments to take steps to end abuse, child marriage and the early pregnancies that lead to thousands of maternal deaths." ("Partnership Will Make Global Goals Count for Girls.")

2. In 2012 the Raise Your Hand petition was launched in order to pressure the "UN to prioritize girls' education in the Global Goals." with the support of 2.3 million people in 2014 it was handed to the UN.

3. To fight against child marriage the Plan International Norway created the fictional blog about "12-year-old Thea who was due to mary 37-year-old Geir". The organization continued to fight for child marriage which stands as a barrier to girls' education. The dedicated hard work has helped "to raise the legal age of marriage for girls to 18 in Zimbabwe, Malawi, Honduras, Guatemala, and El Salvador."

4. In 2015 "International Day of the Girl 2016 saw the first global \#GirlsTakeover. Girls stepped into the shoes of leaders in more than 50 countries to call on their governments to remove the barriers that deny millions their rights and stop girls going to school."

5. In 2016 "Plan International UK delivered a petition signed by people from over 90 countries to the UN calling on governments to improve the safety of cities for girls. After the petition was handed over, UN member states signed the New Urban Agenda which commits them to guarantee girls' safety, access to public spaces and their ability to move freely in cities."

6. In 2018 , " $\$ 2.3$ billion was pledged by donor governments to fund education in low-income countries between 2018 and 2020. This was an increase on the $\$ 1.3$ billion pledged for the previous 3 years. In addition, developing countries increased their collective budget for education from $\$ 80$ billion to $\$ 110$ billion.” In continuation and as a next step the campaign "\#WeAreTheNext" took a step with the request to raise the girls' education funding by governments.

7. UN Women is the United Nations organisation driving gender equality and the empowerment of women. Under the partnership the 2 organisations will work together with boys and young men to achieve gender equality. As PLAN International mentions: "The drive to end all forms of violence against girls and women is also at the forefront of goals that Plan International and UN Women will work on together." Moreover, "Plan International's Because I am a Girl movement has helped transform the lives of almost 5 million girls since it was launched in 2012 while UN Women's Youth and Gender Equality Strategy provides a framework for strengthening initiatives for the empowerment of young women."

\section{REFERENCES}

Bachelet, M. (2012). 'Speech by Michelle Bachelet, Executive Director of UN Women, at the Plan International Because I Am a Girl Launch Event.' UN Women. Retrieved from www.unwomen.org/en/news/stories/2012/10/speech-by-michelle-bachelet-executive-director-ofun-women-at-the-plan-international-because-i-am

Castells, M. (2008). The New Public Sphere: Global Civil Society, Communication Networks, and Global Governance. The ANNALS of the American Academy of Political and Social Science, 616, 78-93.

Kaldor, M. (2005). The Idea of Global Civil Society. In G. Baker \& D. Chandler (Eds.), Contested Futures (pp. 104-113). London: Routledge. 
Plan International. (2016). Partnership Will Make Global Goals Count for Girls. Retrieved from www.plan-international.org/news/2016-05-17-partnership-will-make-global-goals-count-girls

Plan International. (2017). 100 Million Reasons / Strategy. Retrieved from www.planinternational.org/organisation/strategy

Plan International. (2017). Because I Am a Girl - History. Retrieved from www.planinternational.org/because-i-am-a-girl

Plan International. (2017). Girls Get Equal. Retrieved from www.plan-international.org/girls-get-equal

Plan International. (2017). Global Corporate Partnerships. Retrieved from www.planinternational.org/global-corporate-partnerships

Plan International. (2017). Our History. Retrieved from www.plan-international.org/organisation/history

Plan International. (2017). UN and Plan International in Global Action for Girls. Retrieved from www.plan-international.org/press-releases/un-and-plan-international-global-action-for-girls.

Plan International. (2018). Plan International Charity Reveals Child Sex Abuse Cases. BBC News, BBC. Retrieved from www.bbc.com/news/uk-43179696

Plan International. (n.d). Plan International's Push for Girls' Rights at the UN. Retrieved from www.planinternational.org/blog/2016/09/plan-internationals-push-girls-rights-un

Puri, L. (2016). Make the 2030 Agenda Count for All Girls, Everywhere. UN Women. Retrieved from www.unwomen.org/en/news/stories/2016/10/speech-by-un-women-deputy-executive-directorlakshmi-puri-on-bridging-gender-data-gap-for-girls

UN Women. (2016). Partnerships Key to Success of 2030 Agenda for Sustainable Development.

Retrieved from www.unwomen.org/en/news/stories/2016/6/partnerships-key-to-success-of-2030agenda-for-sustainable-development

UN Women. (2017). UN Women Strategic Plan 2018-2021. Retrieved from www.unwomen.org/en/digital-library/publications/2017/8/un-women-strategic-plan-2018-2021

UN Women. (2018). Speak up for gender equality: because gender equality is not an individual's issue. Asia and the Pacific. Retrieved from www.asiapacific.unwomen.org/en/news-andevents/stories/2018/11/speak-up-for-gender-equality

United Nations. (2017). Why It Matters - Goal 17 - Partnerships. Retrieved from www.un.org/sustainabledevelopment/wpcontent/uploads/2017/02/ENGLISH_Why_it_Matters_Goal_17_Partnerships.pdf 